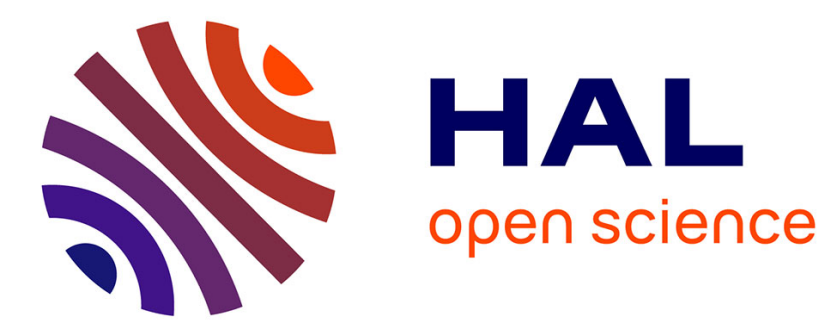

\title{
Dating French and Spanish Prehistoric Decorated Caves in Their Archaeological Contexts
}

Hélène Valladas, Dominique Genty, Evelyne Kaltnecker, Anita Quiles, Nadine

Tisnerat-Laborde, Maurice Arnold, Emmanuelle Delque-Kolic, Christophe

Moreaux, Dominique Baffier, Jean-Jacques Cleyet-Merle, et al.

\section{To cite this version:}

Hélène Valladas, Dominique Genty, Evelyne Kaltnecker, Anita Quiles, Nadine Tisnerat-Laborde, et al.. Dating French and Spanish Prehistoric Decorated Caves in Their Archaeological Contexts. Radiocarbon, 2013, 55 (3-4), pp.1422-1431. 10.1017/S0033822200048359 . hal-01963487

\section{HAL Id: hal-01963487 \\ https://hal.science/hal-01963487}

Submitted on 15 Jun 2021

HAL is a multi-disciplinary open access archive for the deposit and dissemination of scientific research documents, whether they are published or not. The documents may come from teaching and research institutions in France or abroad, or from public or private research centers.
L'archive ouverte pluridisciplinaire HAL, est destinée au dépôt et à la diffusion de documents scientifiques de niveau recherche, publiés ou non, émanant des établissements d'enseignement et de recherche français ou étrangers, des laboratoires publics ou privés. 


\title{
DATING FRENCH AND SPANISH PREHISTORIC DECORATED CAVES IN THEIR ARCHAEOLOGICAL CONTEXTS
}

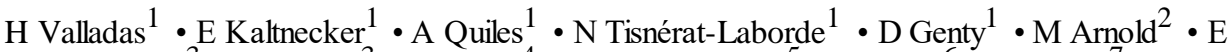 \\ Delqué-KoliE ${ }^{3} \cdot \mathrm{C}^{\text {Moreau }}{ }^{3} \cdot \mathrm{D} \mathrm{Baffier}^{4} \cdot \mathrm{J} \mathrm{J} \mathrm{Cleyet} \mathrm{Merle}^{5} \cdot \mathrm{J}_{\text {Clottes }}^{6} \cdot \mathrm{M} \mathrm{Girard}^{7} \cdot$ \\ $\mathrm{J}_{\text {Monney }}{ }^{8} \cdot \mathrm{R} \mathrm{Montes}^{9} \cdot \mathrm{C} \mathrm{Sainz}^{10} \cdot \mathrm{J} \mathrm{L} \mathrm{Sanchidrian}^{11} \cdot \mathrm{R} \mathrm{Simonnet}^{12}$
}

ABSTRACT. The Laboratoire des Sciences du Climat et de l'Environnement (LSCE) research program on prehistoric art conducts chronological studies of parietal representations with their associated archaeological context. This multidisciplinary approach provides chronological arguments about the creation period of parietal representations. This article presents chrono-logical investigations carried out in several decorated caves in France (La Grande Grotte, Labastide, Lascaux, La Tête-du-Lion, Villars) and Spain (La Garma, Nerja, La Pileta, Urdiales). Several types of organic materials, collected from different areas of the caves close to the walls and in connection with parietal art, were dated to determine the periods of human presence in the cave, a presence that may have been related to artistic activities. These new radiocarbon results range from 33,000-29,000 (La Grande Grotte) to 16,000-14,000 cal BP (Urdiales).

\section{INTRODUCTION}

Developing a chronological framework for Paleolithic parietal art (paintings and drawings) remains a difficult and controversial issue. Indeed, direct radiocarbon dating on paintings is exceptional, primarily because of preservation concerns and also due to the scarcity of organic pigments. Therefore, the results are not numerous and are often challenged. Reservations bear upon the taphonomic evo-lution of cave walls and especially upon the possible presence of extraneous organic materials, which can contaminate the parietal representations and thus distort the dating results. This problem is particularly important in the case of frequently visited caves. The temporal connection between the dated samples and the creation period of paintings or drawings is another difficulty. How can we be certain that the death of the tree whose charcoal was used by prehistoric people is contemporane-ous with the creation of the parietal representations themselves?

That is why ${ }^{14} \mathrm{C}$ dating has also been carried out from organic remains recovered from the archaeological sediments in decorated caves, but connections between these ${ }^{14} \mathrm{C}$ results and the parietal representations are often problematic. Indeed, caves may have been occupied without painting events, and painting events can occur without any other evidence of occupation. Moreover, archaeological investigations reveal that human occupations of caves were relatively frequent during the Pleis-tocene and that archaeological remains underwent complex depositional patterns with erosion and

\footnotetext{
${ }^{1}$ Laboratoire des Sciences du Climat et de l'Environnement (LSCE/IPSL), CEA-CNRS-UVSQ, Avenue de la Terrasse, 91198 Gif-sur-Yvette Cedex, France.

2 Aix-Marseille Université, CNRS-IRD-Collège de France, UM 34 CEREGE, Technopôle de l'Environnement ArboisMédi-terranée, BP80, 13545 Aix-en-Provence, France.

${ }^{3}$ Laboratoire de Mesure du carbone 14, CEA Saclay, 91191 Gif-sur-Yvette Cedex, France.

${ }^{4}$ CREPS, 07150 Vallon Pont d'Arc, France.

${ }^{5}$ Musée National de Préhistoire, 24620 Les Eyzies de Tayac, France.

611 rue du Fourcat, 09000 Foix, France.

7342 Boulevard des Horizons, 06220 Vallauris, France.

${ }^{8}$ Centre National de Préhistoire, 38 rue du 26ème R.I., 24000 Périgueux, France.

${ }^{9}$ Museo Nacional y Centro de Investigación de Altamira, Spain.

${ }^{10}$ Universitad de Cantabria, dpto. Sciencias Historicas, 39005 Santander, Spain.

${ }^{11}$ Universitad de Cordoba, Area Prehistoria, Departamento de Geografía y Ciencias del Territorio, Plaza Cardenal Salazar s/n, 14071, Cordoba, Spain.

1228 allée de la Limagne, 31300 Toulouse, France.
} 
deposition periods that disturbed the integrity of the stratigraphic sequences. However, for certain caves whose geological context is well studied, a multidisciplinary approach provides arguments to propose chronological connections between their archaeological deposits and parietal representa-tions. Such connections will not date the paintings and drawings themselves, but they appear to pro-vide the most parsimonious interpretation, and therefore, they give valuable and precious informa-tion to place the representations within a chronological framework.

In this article, we will first present ${ }^{14} \mathrm{C}$ results obtained from organic remains sampled on the wall (torch wipes and dots) or in the archaeological sediments of French decorated caves (La Grande Grotte, Labastide, Lascaux, Villars, Table 1) and then we will discuss direct ${ }^{14} \mathrm{C}$ dating for drawings from 3 Spanish caves (La Garma, Urdiales, and La Pileta; see Table 2).

\section{THE DECORATED DATED CAVES}

With the exception of La Pileta (Andalusia), belonging to private owners, the decorated caves (Tables 1 and 2) presented in this article have been the subject of multidisciplinary research for sev-eral years. Our program included fieldwork to refine the stratigraphic sequence and the site formation processes. This provided information on human presence locations in the cave as well as on the occu-pation periods thanks to previous ${ }^{14} \mathrm{C}$ dating (in italics in Tables 1 and 2). Also, when lithic remains were available, they were analyzed and the parietal representations were thoroughly described. We will first briefly describe these decorated caves and their archaeological context, then emphasize the connection between their contextual remains and parietal representations.

La Grande Grotte (Arcy-sur-Cure, Yonne; Baffier and Girard 1998, 2013) has been intensively studied by the D Baffier and M Girard's team for about $20 \mathrm{yr}$, since the discovery of red and black parietal representations. More than 200 representations (engravings, paintings, and drawings) have been found and studied so far. Calcitic deposits have covered the charcoal drawings, so direct ${ }^{14} \mathrm{C}$ dat-ing has not been possible so far. However, the choice of species (mammoths, lion, rhinoceros, etc.) for the animal depictions at La Grande Grotte d'Arcy and their similarity to some ancient parietal art, such as that of Chauvet-Pont d'Arc Cave (Clottes 1996, 2001; Baffier and Girard 1998, 2012; Val-ladas et al. 2001a) suggests that the Arcy decoration could be attributed to the Aurignacian-Gravet-tian period (Figure 1; Girard et al. 1996; Baffier and Girard 1998). Test excavations in different sec-tors of the cave revealed the existence of a thin archaeological layer encompassed in sterile sediments layers bracketed by 2 stalagmitic deposits. They have been dated by the uranium series method to 53,410 $\pm 160 \mathrm{yr}$ BP for the deepest and $13,730 \pm 90 \mathrm{yr}$ BP for the youngest, which corresponds to the current ground surface (L Ayliffe, personal communication, 2000) . In particular, 2 excavations located near the decorated wall yielded anthropic remains in connection with wall decorations, which are particularly interesting from a chronological point of view. Near La Corniche au Bison (P68-69), the archaeological layer contained the remains of a small hearth on top of which an ochred stalag-mitic fragment and a partly burned cave bear metatarsal bone with an ochred epiphysis had been deposited. Near that structure, 2 drops of red paint were found: their chemical composition is similar to that of the red paintings located on the panel above. Test excavation J81-82 along the La Salle des Noyaux de Cerises wall yielded remains (yellow ochre, red powder, grinding stone) from the prep-aration of color in the archaeological layer in contact with the upper stalagmitic layer. The new ${ }^{14} \mathrm{C}$-dated samples (charcoal and burnt bones) were collected in these interesting structures.

The first investigations in La Tête-du-Lion Cave (Combier 1984; Monney et al. 2013) go back to the 1970s. Red drawings were discovered then. They represent a bovid, 2 ibex heads, a stag, and at least 2 groups of red dots located in a concave part of the wall called the Apse (L'Abside). Excava-tions carried out at $1.20 \mathrm{~m}$ from the painted wall revealed a single archaeological layer without any 
lithic industry but containing remains of a fire with several Pinus sylvestris charcoal fragments and at least 4 ochred drops $2-3 \mathrm{~cm}$ in diameter, which were interpreted as being pigment remains. These drops made of hematite had the same composition as the pigment used for the bovid image but a dif-ferent one from those used for the stag and dots. The first ${ }^{14} \mathrm{C}$ dating of the charcoal fragments gave a Solutrean age in agreement with stylistic expectations (Leroi- Gourhan's Style III) but with a rather large margin of error, 21,650 $\pm 800 \mathrm{BP}$ (Evin et al. 1975). In the course of recent excavations by Monney et al. (2013) in the vicinity of the Apse, the archaeological layer yielded new charcoal frag-ments whose dating will be presented hereafter.

The Lascaux (Montignac; Aujoulat 2004) and Villars caves (Villars; Delluc and Delluc 1974) in the Dordogne, discovered respectively in 1940 and 1953, have been extensively studied and are well known. The representations in each cave show a great unity as well as stylistic and thematic affini-ties between them (i.e. Leroi-Gourhan's Style III) . In both caves, for instance, there are representa-tions of a man facing a bison, a rather rare scene. This similarity raises the question of the possible contemporaneity of their decorations (Delluc and Delluc 1984; Baffier 1988) and emphasizes the necessity to get some accelerator mass spectronomy (AMS) dates for these caves. It is not possible to directly date the Lascaux and Villars paintings because physical-chemical analyses revealed that their black color was obtained from manganese dioxide and therefore did not contain any organic residue (Beck et al., these proceedings). Contrary to Villars, where scarce anthropic remains are scattered on the ground, the Lascaux archaeological layer provided a wealth of lithic and bone work, stone lamps, animal bones, and charcoal fragments. In the $1960 \mathrm{~s}$, ${ }^{14} \mathrm{C}$ dates (in italics in Tables 1 and 2) were obtained for the Lascaux cave by US (Libby, Chicago) and European laboratories (Gronin-gen and Saclay). Three of them were in the $17,000-15,000{ }^{14} \mathrm{C}$ yr BP time range and the 8 others during the Holocene, from 7000 to $5000{ }^{14} \mathrm{C} \mathrm{BP}$ (Delibrias et al. 1964; Leroi-Gourhan and Evin 1979; Aujoulat et al. 1998; Glory 2008). Because of the scarcity and the dispersion of these first ${ }^{14} \mathrm{C}$ dates, it was important to refine the Lascaux occupation period by dating other organic samples by AMS in close association with cultural activities. The Lascaux selected samples were fragments from a spear and from a reindeer antler, while the only available samples for Villars were parietal torch wipes and burnt (or unburnt) bones.

Discovered in 1932, the decorated cave of Labastide (Labastide, Hautes Pyrénées), as well as other Pyrenean caves such as Niaux, Bédeillac, Enlène, and Le Portel, is attributed to the Middle Magdalenian period (Simonnet et al. 1984; Simonnet 1993). Magdalenian occupations have left remains of well-preserved hearths, lithic artifacts, animal bones, and many engraved stone plaquettes and carved bones on or near the soil surface all along the cave. Like the lithic tools and mobile art objects, the parietal paintings and engravings are also typical of the Middle Magdalenian (Leroi-Gourhan's Style IV). Four conventional ${ }^{14} \mathrm{C}$ dates were obtained in the $1980 \mathrm{~s}$ on burnt bones by the Gif-sur-Yvette and Lyon laboratories from samples including several pieces of bones, some of which could have been contaminated. A few years later, we decided to carry out some new dates on single pieces of burnt and unburnt bones.

Finally, in the case of La Garma, the associated samples (bone specimens and artifacts) were AMS dated by the Oxford Laboratory, while a charcoal splinter taken from a vertical bison drawing was measured at Gif-sur- Yvette. These decorated caves are located in Spain (Table 2): La Garma and Urdiales (Cantabria; González Sainz 2007; Univ. of Cantabria 1999), Nerja and La Pileta (Andalu-sia; Sanchidrián Torti 1994). 
Table 1 Data and ${ }^{14} \mathrm{C}$ results for the French caves. Parietal samples (drawings and torch rubbings) are given in bold and previously obtained ${ }^{14} \mathrm{C}$ results in italics.

\begin{tabular}{|c|c|c|c|c|c|c|}
\hline & & & & & & Calibrated age \\
\hline \multirow{14}{*}{$\begin{array}{l}\text { Cave } \\
\text { Labastide }\end{array}$} & Sector & Sample & Lab code & $\mathrm{mg} \mathrm{C}$ & ${ }^{14} \mathrm{C}$ age $\mathrm{BP}(1)$ & 2 \\
\hline & Gisement1 $(100 \mathrm{~m})$ & Bone & GifA 99423 & 0.7 & $13,870 \pm 130$ & $16,705-17,402$ \\
\hline & Bloc B5 & Bone & GifA 99104 & 1.2 & $14,150 \pm 130$ & $16,874-17,624$ \\
\hline & Bloc B5 & Parietal mark (LBT5, P20) & GifA 98181 & 0.82 & $480 \pm 50$ & $334-634$ \\
\hline & Diverticule & Burnt bone & GIF 6367 & & $12,700 \pm 110$ & $14,240-15,608$ \\
\hline & Diverticule & Burnt bone & GIF 6612 & & $13,500 \pm 120$ & $15,975-16,938$ \\
\hline & Diverticule & Burnt bone & GIF 6611 & & $13,700 \pm 120$ & $16,527-17,101$ \\
\hline & Diverticule & Burnt bone & GifA 102394 & 0.94 & $13,610 \pm 120$ & $16,374-17,029$ \\
\hline & Diverticule & Stuck bone (LB OF8) & GifA 99105 & 2.35 & $14,010 \pm 140$ & $16,800-17,506$ \\
\hline & Diverticule & Parietal mark (LBT29) & GifA 98182 & 0.76 & $1240 \pm 60$ & $1010-1290$ \\
\hline & Diverticule & Parietal mark (LBT22) & GifA 98183 & 0.31 & $-170 \pm 60$ & \\
\hline & Gisement Casteret $2(400 \mathrm{~m})$ & Bone & LY405 & & $14,250 \pm 440$ & $16,427-18,563$ \\
\hline & Gisement Casteret $2(400 \mathrm{~m})$ & Bone & GifA 99424 & 0.74 & $14,360 \pm 120$ & $17,077-17,875$ \\
\hline & Gisement Casteret $2(400 \mathrm{~m})$ & Parietal mark (23TC) & GifA 100391 & 1.66 & $1110 \pm 70$ & 912-1238 \\
\hline \multirow[t]{5}{*}{ Lascaux } & Puits & Charcoal & C 406 & & $15,516 \pm 900$ & $16,747-20,949$ \\
\hline & Passage & Charcoal & GrN 1632 & & $17,190 \pm 140$ & $20,046-21,122$ \\
\hline & Puits & Charcoal & Sa 102 & & $16,000 \pm 500$ & $18,060-20,276$ \\
\hline & Puits & Spear bone & GifA 101110 & 1.64 & $18,930 \pm 230$ & $22,088-23,359$ \\
\hline & Puits & Reindeer antler (III-48) & GifA 95582 & 1.62 & $18,600 \pm 190$ & $21,507-22,584$ \\
\hline \multirow[t]{12}{*}{ Villars } & Entrance (LB784) & Charcoal & GifA 90216/SacA 14201 & 0.48 & $985 \pm 30$ & 796-959 \\
\hline & Soil surface & Burnt bone & GifA 09508/SacA 18206 & 0.27 & $16,730 \pm 80$ & $19,565-20,193$ \\
\hline & Soil surface & Burnt bone & GifA $11013 /$ SacA 23428 & 1.11 & $16,100 \pm 80$ & $18,933-19,435$ \\
\hline & Hearth & Burnt bone & & & $16,480 \pm 210$ & $18,987-20,235$ \\
\hline & Soil surface & Reindeer bone & GifA 10177/SacA 19773 & 1.37 & $18,420 \pm 130$ & $21,530-22,334$ \\
\hline & Soil surface & Reindeer bone & GifA 10118/SacA 19774 & 1.36 & $18,470 \pm 130$ & $21,551-22,370$ \\
\hline & Soil surface & Reindeer bone & GifA 10053/SacA 19021 & 1.16 & $18,790 \pm 140$ & $22,065-23,233$ \\
\hline & Chapelle du balcon & Charcoal parietal mark & GifA 09393/SacA 15482 & 0.5 & $17,460 \pm 90$ & $20,397-21,247$ \\
\hline & Chapelle du balcon & Charcoal parietal mark & GifA 10313/SacA 23086 & 6.53 & $18,150 \pm 110$ & $21,356-22,114$ \\
\hline & Chatière & Charcoal parietal mark & GifA 10316/SacA 23089 & 0.41 & $17,680 \pm 100$ & $20,544-21,434$ \\
\hline & Carrefour, below black triangle & Charcoal parietal mark & GifA 10314/SacA 23087 & 0.17 & $14,350 \pm 90$ & $17,104-17,842$ \\
\hline & Carrefour, in front of black triangle & Charcoal parietal mark & GifA 10315/SacA 23088 & 0.36 & $14,610 \pm 90$ & $17,265-18,054$ \\
\hline \multirow[t]{2}{*}{ Tete-du-lion } & Alcôve de la vache & Charcoal & GifA 10296/SacA 23069 & 1.18 & $22,120 \pm 150$ & $26,018-27,502$ \\
\hline & Alcôve de la vache & Charcoal & Ly 847 & & $21,650 \pm 800$ & $24,005-27,988$ \\
\hline \multirow[t]{2}{*}{$\begin{array}{l}\text { Grande Grotte } \\
\text { Arcy-sur-Cure }\end{array}$} & $\begin{array}{l}\text { Salle des Noyaux de Cerises } \\
\text { "Panneau des mains" }\end{array}$ & Burnt bone & GifA 102383 & 0.59 & $24,470 \pm 240$ & $28,497-29,848$ \\
\hline & Corniche au Bison & Burnt bone & GifA 95620 & 0.93 & $27,950 \pm 440$ & $31,340-33,255$ \\
\hline
\end{tabular}


Table 1 Data and ${ }^{14} \mathrm{C}$ results for the French caves. Parietal samples (drawings and torch rubbings) are given in bold and previously obtained ${ }^{14} \mathrm{C}$ results in italics.

\begin{tabular}{|c|c|c|c|c|c|c|}
\hline \multirow[t]{16}{*}{ Cave } & Sector & Sample & Lab code & $\mathrm{mg} \mathrm{C}$ & ${ }^{14} \mathrm{C}$ age $\mathrm{BP}(1)$ & $\begin{array}{l}\text { Calibrated age } \\
2\end{array}$ \\
\hline & Corniche au Bison & Burnt bone & GifA 93008 & 2.08 & $24,700 \pm 360$ & $28,629-30,302$ \\
\hline & Corniche au Bison & Burnt bone & GifA 94589 & 2.19 & $26,700 \pm 410$ & $30,485-31,657$ \\
\hline & Corniche au Bison & Torch rubbing & GifA 98184 & 0.48 & $26,470 \pm 390$ & $30,410-31,445$ \\
\hline & Corniche au Bison & Torch rubbing & GifA 98185 & 0.47 & $27,080 \pm 400$ & $30,878-32,290$ \\
\hline & Corniche au Bison & Burnt bone & OxA 5003 & & $26,250 \pm 500$ & $29,795-31,491$ \\
\hline & Salle des Vagues & Fresh bone & GifA 93012 & 0.45 & $29,640 \pm 590$ & $32,613-35,276$ \\
\hline & Salle des Vagues & Horse tooth & GifA 93013 & 0.68 & $30,160 \pm 640$ & $33,315-36,294$ \\
\hline & Salle des Vagues & Burnt bone & GifA 95619/CP & 0.43 & $25,930 \pm 360$ & $29,800-31,213$ \\
\hline & Salle des Vagues & Burnt bone & GifA 96680 & 2.06 & $27,280 \pm 330$ & $31,070-32,287$ \\
\hline & Salle des Vagues & Burnt bone & GifA 97339 & 1.8 & $28,010 \pm 350$ & $31,451-33,136$ \\
\hline & Salle des Vagues & Charcoal & GifA 102382 & 0.89 & $26,750 \pm 260$ & $30,907-31,504$ \\
\hline & Salle des Vagues & Charcoal & GifA 91370 & & $28,250 \pm 430$ & $31,418-33,854$ \\
\hline & Salle des Vagues & Burnt bone & GifA 92330 & & $27,630 \pm 400$ & $31,216-32,878$ \\
\hline & Salle des Vagues & Fresh bone & GifA 97146 & 0.91 & $41,200 \pm 2300$ & $41,689-49,318$ \\
\hline & Salle des Vagues & "Black pollution" & GifA 98178 & 0.63 & $1480 \pm 60$ & 1295-1455 \\
\hline
\end{tabular}

Table 2 Data and ${ }^{14} \mathrm{C}$ results for the Spanish caves. The parietal samples (drawings and torch rubbings) are given in bold and the previously obtained ${ }^{14} \mathrm{C}$ results in italics.

\begin{tabular}{|c|c|c|c|c|c|}
\hline Cave & Sample & Lab code & $\operatorname{mg~C}$ & $\begin{array}{l}{ }^{14} \mathrm{C} \text { age } \\
(\mathrm{BP})(1)\end{array}$ & $\begin{array}{l}\text { Calibrated age } \\
\text { BP (2) }\end{array}$ \\
\hline Urdiales & B ison representation 2 & GifA $11454 /$ SacA 26196 & 0.12 & $12,750 \pm 110$ & $14,545-15,901$ \\
\hline \multirow{5}{*}{ La Garma } & Fresh bone, 34 & $O x A 8721$ & & $14,050 \pm 110$ & $16,837-17,491$ \\
\hline & Fresh bone, 36 & $O x A 8722$ & & $13,610 \pm 100$ & $16,447-16,991$ \\
\hline & Fresh bone & $O x A 7203$ & & $12,070 \pm 100$ & $13,703-14,185$ \\
\hline & Harpoon (Cervus elaphus antler), 26 & OxA 8720 & & $11,470 \pm 150$ & $13,080-13,715$ \\
\hline & Vertical bis on representation $(\mathrm{IX}, 1)$ & GifA 102581 & & $13,780 \pm 150$ & $16,512-17,238$ \\
\hline Nerja & Charcoal (GN6) & GifA 98191 & 1.26 & $19,900 \pm 210$ & $23,261-24,381$ \\
\hline \multirow[t]{3}{*}{ La Pileta } & Aurochs representation & GifA 98162 & 0.39 & $20,310 \pm 350$ & $23,391-25,065$ \\
\hline & Charcoal (LP4) & GifA 98158 & 0.52 & $3760 \pm 60$ & $3928-4400$ \\
\hline & Paleosol (LP2) & GifA 98176 & 2.31 & $3880 \pm 70$ & $3464-3828$ \\
\hline
\end{tabular}




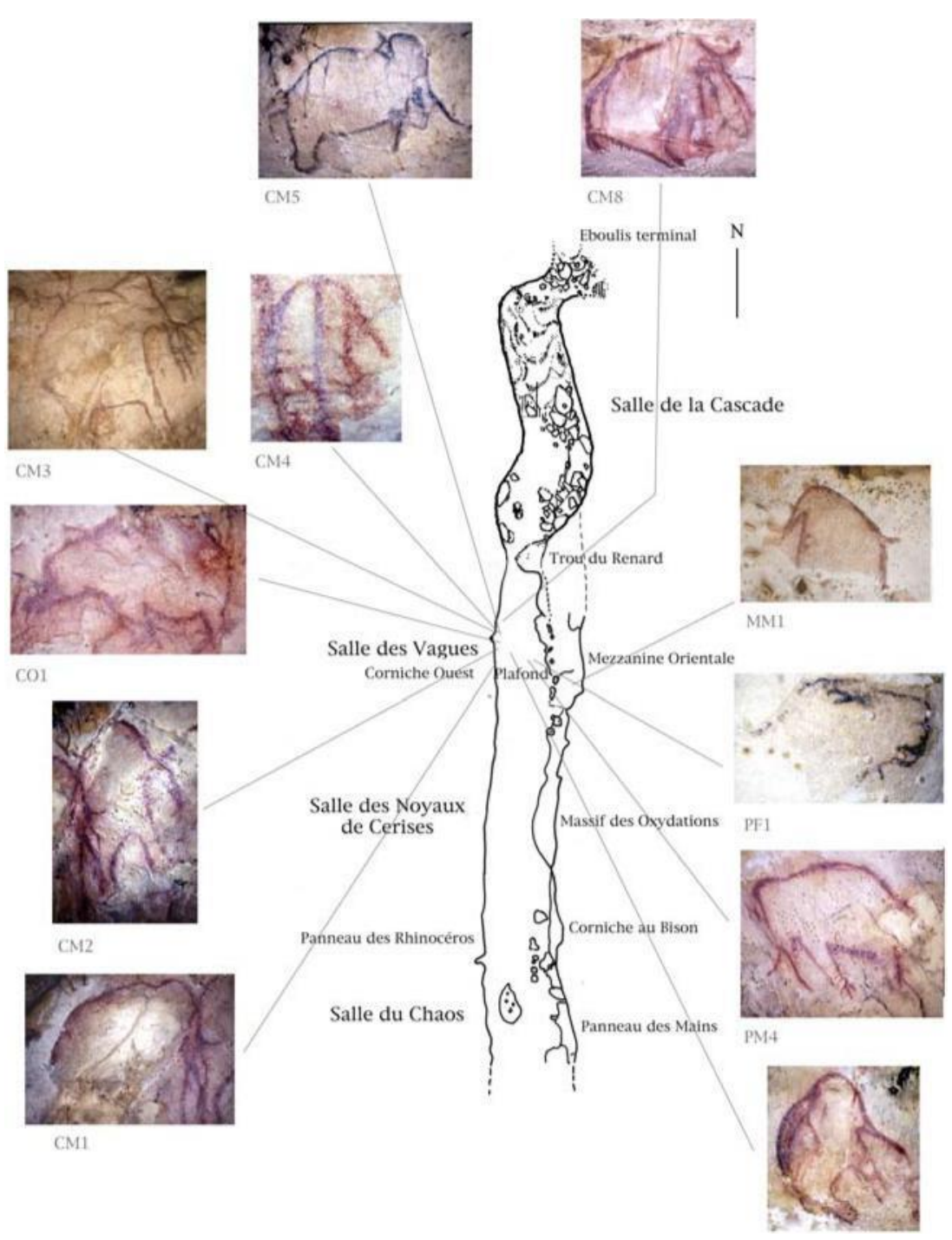

Figure 1 The main paintings in La Salle des Vagues at La Grande Grotte (Arcy-sur-Cure, Yonne; Baffier and Girard 1998).

\section{MATERIALS AND METHODS}

Whenever possible, we chose organic samples (Tables 1 and 2) associated with artistic activities, such as pigment remains (La Grande Grotte at Arcy and La Tête -du-Lion). We also selected material in close association with past human activities: parietal black marks and possible torch wipes at Labastide, Villars, and La Grande Grotte; a spearhead at Lascaux; a piece of bone purposely stuck into a crack of the wall at Labastide; and burnt bone fragments and pieces of charcoal originating from cave hearths at Villars, Labastide, and La Grande Grotte. Moreover, it was possible to directly date some animal representations such as the aurochs at La Pileta, the bison 2 at Urdiales, and the vertical bison at La Garma A (in bold in Tables 1 and 2). Finally, fresh bone specimens (3 reindeer fragments at Villars and 4 at La Grande Grotte) were also dated, even though these kinds of samples are less reliable, as they may have been brought into the caves by carnivores. 
Due to a lack of samples, it was impossible to get more than 2 extra ${ }^{14} \mathrm{C}$ dates in the case of La Pileta and Lascaux and only 1 at La Garma, Nerja, and La Tête-du-Lion. On the other hand, we were able to get at least 10 dates at La Grande Grotte, Labastide, and Villars where available organic materials were more abundant.

The charred bone and charcoal specimens were pretreated by the acid-base- acid (ABA) method. Whatever remained was oxidized to carbon dioxide, then reduced to graphite and compressed into pellets, which were submitted to the Tandetron through 2004 and to the Artemis AMS facilities after 2005 (Arnold et al. 1989). When available, the alkaline fractions resulting from the chemical pretreatment were also dated (Batten et al. 1986). In the case of parietal samples (paintings and torch wipes), the pretreated charcoals collected on a precleaned quartz filter were heated in a stream of oxygen for about $1 \mathrm{hr}$ between 280 and $320^{\circ} \mathrm{C}$ to remove any additional organic contaminants.

Bone sample preparation is based on the specific reaction between the collagen amino acids and the ninhydrin reagent (Nelson 1991), which allowed us to extract the $\mathrm{CO}_{2}$ from the carboxylic groups of amino acids (Tisnérat-Laborde et al. 2003). The extracted $\mathrm{CO}_{2}$ was reduced to graphite (Arnold et al. 1989), which was then AMS dated.

\section{RESULTS}

The ${ }^{14} \mathrm{C}$ results and their calibrated ages obtained for each cave are given in Tables 1 (French caves) and 2 (Spanish caves). Figure 2 shows the calibrated ages deduced for the Spanish caves (using CALIB v 6; Stuiver et al. 2010). At Nerja, the 23,260-24,380 cal BP age for the charcoal sample found on a ledge a few $\mathrm{cm}$ below the stag representation falls into the Solutrean period, a result sim-ilar to the one obtained for the aurochs representation of La Pileta Sanctuary $(23,390$ 25,065 cal BP), evidence of parietal art being made then in southern Spain. La Pileta was al so visited during the Chalcolithic period as attested by the ages between 3900 and $3500 \mathrm{cal} \mathrm{BP}$ obtained from a comb-shaped drawing and a paleosol deposit.

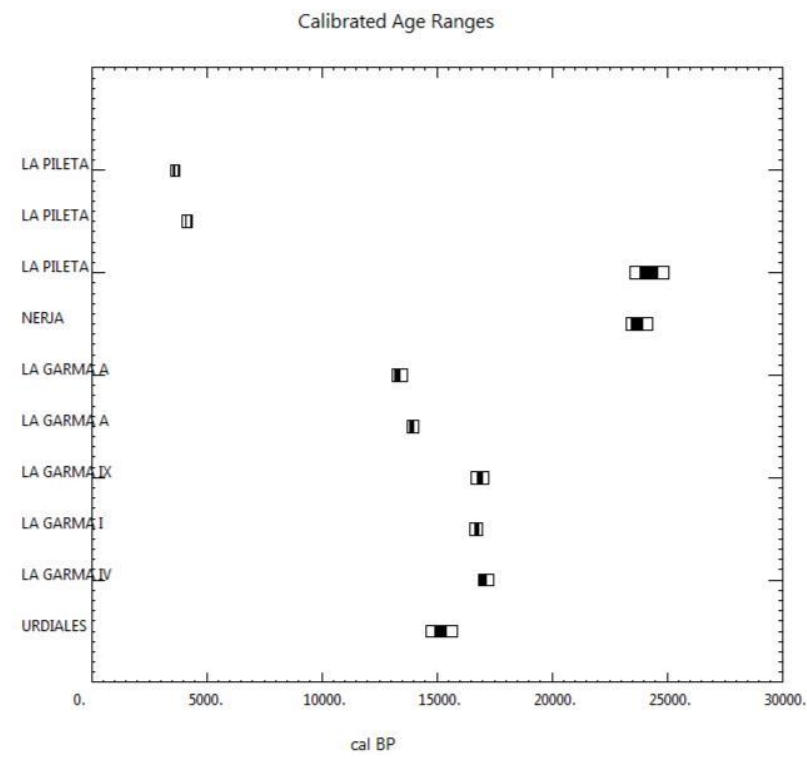

Figure 2 Calibrated ages (using OxCal v 6; Stuiver et al. 2010; IntCal09, Reimer et al. 2009) obtained for the Spanish caves. 
Two successive occupation periods $(17,500-16,500$ and $14,200-13,000$ cal BP) during the Magdalenian were revealed by the 4 bone specimens dated at La Garma. The vertical bison representation (area IX) (17,240-16,510 cal BP) falls within the first period of occupation. These results are quite similar to those previously obtained for the 3 Altamira and 2 Covaciella (Cantabria) bison representations, which range between 18,000 and 16,500 cal BP (Valladas et al. 2001b). The Urdi-ales bison 2 appears to be younger (15,900-14,500 cal BP) and falls into the same time interval as the Magdalenian El Castillo bison (16,800-14,000 cal BP; Valladas et al. 2001b). Dates obtained for the French caves range from $\sim 33,000$ to 16,000 cal BP (Table 1 and Figure 3).

Calibrated Age Ranges

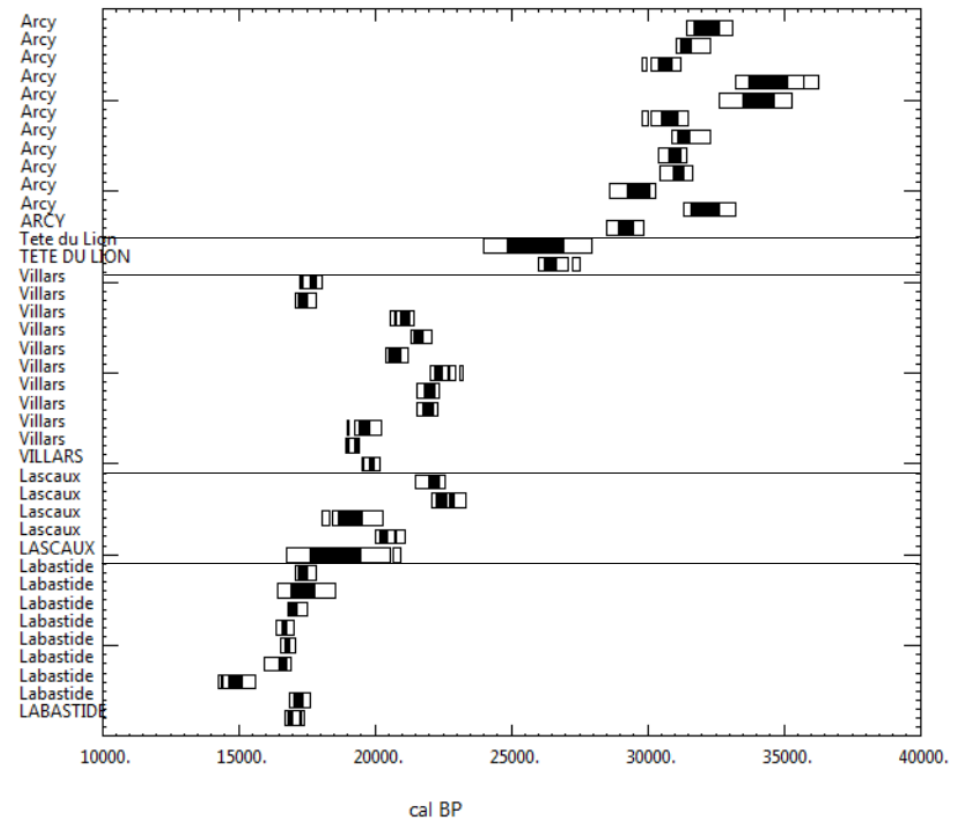

Figure 3 Calibrated ages (using OxCal v 6; Stuiver et al. 2010; IntCal09, Reimer et al. 2009) obtained for the French caves.

The new results for Labastide are in agreement with those obtained in the 1980s, and are included in the 17,500 and 16,000 cal BP time interval. They show that all the cave areas including those with parietal representations were intensively visited by Magdalenian people. Some parietal marks that had earlier been attributed to Paleolithic activities, however, now appear to date to the Holocene.

The new Lascaux results on a spearhead and reindeer antler fragments $(23,000-22,000 \mathrm{cal} \mathrm{BP})$ are somewhat older than those obtained in the 1960s on charcoal specimens $(21,000-17,000 \mathrm{cal} \mathrm{BP})$. They suggest that Lascaux may have been visited by prehistoric people earlier than suspected, but more dates on characteristic bone artifacts are still needed to support this hypothesis.

Until now, the prehistoric human occupations in Villars Cave were known from a single ${ }^{14} \mathrm{C}$ dating (20,500-19,000 cal BP) obtained about $15 \mathrm{yr}$ ago from a burnt bone fragment (unpublished data). New results from parietal torch wipes and black spots provide more information about past human occupations. All these marks were first analyzed by a portable fluorescent X-ray apparatus that allows discarding of all black spots/lines/drawings that were made with manganese dioxide (Beck et 
al., these proceedings). They display 2 distinct sets of dates a few thousand years apart: 3 black spots, among which one is situated near La Salle des Peintures, gave 22,000-20,500, while 2 others yielded $18,000-17,000$ cal BP. The $3{ }^{14} \mathrm{C}$ ages $(23,000-21,500 \mathrm{cal} \mathrm{BP})$ on reindeer bone fragments are slightly older than the oldest parietal marks. These new results are in agreement with the parietal art stylistic investigations and suggest that the cave decoration was created during the ancient Magdalenian period.

Recent excavations by J Monney and more precise AMS ${ }^{14} \mathrm{C}$ dating $(27,000-26,000 \mathrm{cal} \mathrm{BP})$ at La Tête-du -Lion cave confirmed the presence of prehistoric people in the vicinity of the parietal aurochs drawing during the Solutrean period. As indicated by the archaeological association of ochre with the charcoal dated in the 1970s, this event is probably linked with the decoration of the Apse.

Sixteen dates have been made for La Grande Grotte (Arcy-sur-Cure) Upper Paleolithic occupations. The samples of anthropic origin (charred bone and charcoal fragments, parietal marks) were all collected in the vicinity of the decorated walls: below the red figurations painted on La Salle des Vagues ceiling; in an area containing a small hearth and 2 red paint drops (eastern wall, Corniche au Bison) and along a painted panel (western wall, Frise Rouge) of La Salle des Noyaux de Cerises. The samples from torch wipes were also collected in that chamber. Most of the ages are in agree-ment and fall into the 33,000-29,000 cal BP time period. Note that a fresh bone and a tooth collected in La Salle des Vagues gave ages slightly older $(36,000-33,000 \mathrm{cal} \mathrm{BP})$, which can testify to a more ancient occupation. All the results obtained for La Grande Grotte are coherent and correspond to the beginning of the Upper Paleolithic. Therefore, they support the archaeological interpretation that they are characteristic of the Aurignacian-Gravettian tradition (Baffier and Girard 1998).

\section{CONCLUSION}

Decorated caves (La Pileta, Nerja, La Garma, Urdiales, Labastide, Lascaux, Villars, La Tête-duLion at Bidon, and La Grande Grotte at Arcy-sur-Cure) yielded organic remains, which have been dated by the ${ }^{14} \mathrm{C}$ method. The results obtained on these associated samples gave very informative data that allow us to precisely know the occupation periods of those caves. They range from the beginning of the Upper Paleolithic with La Grande Grotte at Arcy-sur-Cure (33,000-29,000 cal $\mathrm{BP})$ to the Magdalenian period with Villars $(22,000-18,000$ cal BP) and Labastide $(18,000-16,500$ cal BP). For most of those caves, direct dating of parietal representations was impossible because of the lack of organic pigment. Therefore, whenever feasible, it becomes essential to establish the chronol-ogy of human occupations in all decorated caves based on their archaeological context. At present, ${ }^{14} \mathrm{C}$ dating appears to be the most relevant method to achieve such an aim.

\section{ACKNOWLEDGMENTS}

We would like to acknowledge Martine Paterne for her interest in this work and our reviewer for his helpful comments. We would like to thank Clothilde Comby-Zerbino for her contribution during the graphitization of the $\mathrm{CO}_{2}$ samples. This work was supported by the French CNRS and the CEA, LSCE contribution $n^{\circ} 5002$.

\section{REFERENCES}

Arnold M, Bard E, Maurice P, Valladas H, Duplessy JC. $1989 .{ }^{14} \mathrm{C}$ dating with the Gif-sur- Yvette Tandetron ac-celerator: status report and study of isotopic fraction-ation in the sputter ion source. Radiocarbon 31(3): 284-91.
Aujoulat N. 2004. Lascaux. Le geste, l'espace et le temps. Paris: Seuil.

Aujoulat N, Cleyet-Merle JJ, Gaussen J, Tisnérat N, Valladas H. 1998. Approche chronologique de quelques sites ornés paléolithiques du Périgord par datation ${ }^{14} \mathrm{C}$, 
en spectrométrie de masse par accélérateur, de leur mobilier archéologique. Paléo 10:319-23.

Baffier D, Girard M. 1998. Les cavernes d'Arcy-surCure, La maison des roches. Paris: Collections Terres Préhistoriques. 120 p.

Baffier D, Girard M. 2013. L'art pariétal gravettien du nord de la France. In: Otte M, director. Les Gravet tiens. Paris-Arles: éditions Errance (Collection Civilis ations et Cultures ). p 215-34.

Batten RJ, Gillespie R, Gowlett JAJ, Hedges REM. 1986. The AMS dating of separate fractions in archaeology. Radiocarbon 28(2A):698-701.

Beck L, Genty D, Lahlil S, Lebon M, Tereygeol F, Vignaud C, Reiche I, Lambert E, Valladas H, Kaltnecker E, Plassard F, Menu M, Paillet P. 2013. Non-destructive portable analytical techniques for carbon in-situ screening before sampling for dating prehistoric rock paintings. Radiocarbon, these proceedings, doi: 10.2458/azu_js_rc.55.16248.

Combier J. 1984. La grotte de la Tête-du-Lion à Bidon (Ardèche). In: L'art des Cavernes. Paris: Ministère de la Culture Imprimerie nationale. p 595-9.

Delibrias G, Guillier MT, Labeyrie J. 1964. Saclay natu-ral radiocarbon measurements I. Radiocarbon $6: 233-50$.

Evin J, Marten G, Pachiaudi C. 1975. Lyon natural radiocarbon measurements V. Radiocarbon 17(1):4-34

Girard M, Baffier D, Tisnerat N, Valladas H, Arnold M, Hedges R. 1996. Dates ${ }^{14} \mathrm{C}$ en spectrométrie de masse par accélérateur à la Grande Grotte d'Arcysur-Cure (Yonne). Cahiers Archéologiques de Bourgogne 6: 17-23.

Glory A. 2008. Les recherches à Lascaux (1952-1963). Gallia Préhistorique. XXXIXe supplément. Paris: CNRS Editions. 196 p.

González Sainz C. 2007. Dating Magdalenian art in north Spain: the current situation. In: Pettitt P, Bahn P, Ripoll S, editors. Palaeolithic Cave Art at Creswell Crags in European Context. Oxford: Oxford University Press. p 247-62.

Leroi-Gourhan A, Evin J. Lascaux inconnu. XIIe s upplément à Gallia Préhis toire. Paris: CNRS. 379 p.
Monney J, Combier J, Kaltnecker E, Lateur N, Moreau C, Stocchetti S, Valladas H. 2013. Nouveaux éléments de discussion chronologiques dans le paysage des Grottes ornées de l'Ardèche: Oulen, Chabot et Tête-du-Lion. Actes du colloque MADAPCA, Novembre 2011, Paris . Paléo: hors série 2013.

Nelson DE. 1991. A new method for carbon isotopic analysis of protein. Science 251(4993):552-4.

Reimer PJ, Baillie MGL, Bard E, Bayliss A, Beck JW, Blackwell PG, Bronk Ramsey C, Buck CE, Burr GS, Edwards RL, Friedrich M, Grootes PM, Guilders on TP, Hajdas I, Heaton T, Hogg AG, Hughen KA, Kaiser KF, Kromer B, McCormac FG, Manning SW, Reimer RW, Richards DA, Southon JR, Talamo S, Turney CSM, van der Plicht J, Weyhenmeyer CE. 2009. IntCal09 and Marine09 radiocarbon age calibration curves, $0-50,000$ years cal BP. Radiocarbon 51(4): 1111-50.

Sanchidrián Torti JL. 1994. Arte Rupestre de la Cueva de Nerja. Trabajos sobre la Cueva de Nerja, 4. Málaga: Patronato de la Cueva de Nerja. 344 p.

Simonnet R. 1993. Les techniques de représentation dans la grotte ornée de Labastide (Hautes-Pyrénées). Con-grès National des Sociétés historiques et scientifiques 118è Pau. p 341-52.

Simonnet G, Simonnet L, Simonnet R. 1984. Grotte de Labastide. In: l'Art des Cavernes: Atlas des grottes ornées paléolithiques françaises. Paris: Ministère de la Culture, Imprimerie Nationale. p 527-35.

Stuiver M, Reimer PJ, Reimer R. 2010. CALIB radiocarbon calibration. URL: http://calib.qub.ac.uk/calib/.

Tisnérat-Laborde N, Valladas H, Kaltnecker E, Arnold M. 2003. AMS radiocarbon dating of bones at LSCE. Radiocarbon 45(3):409-19.

Valladas H, Tisnérat-Laborde N, Cachier H, Arnold M, Bernaldo De Quiros F, Cabrera-Valdes V, Clottes J, Courtin J, Fortea-Perez J, Gonzales-Sainz C, MoureRomanillo A. 2001a. Radiocarbon AMS dates for Paleolithic cave paintings. Radiocarbon 43(2B):977-86.

Valladas H, Clottes J, Geneste JM, Garcia M, Arnold M, Cachier H, Tisnérat -Laborde N. 2001b. Evolution of prehis toric cave art. Nature 413(6855):79. 